\title{
An Outline of the Relations between \\ Viet Nam and Other Southeast Asian Countries in Ancient, Middle Age and Modern History
}

\section{Văn Tạo}

The cultural-historical region of Southeast Asia has played an active role in the history of human evolution. Its regional identity is conditioned, apart from geographical factors and a common cultural-historical provenance, by the economic, cultural and social intercourse that has long existed, and that is considered to be an important factor. This intercourse has increased and has played a crucial role in the formation of the region since the emergence of various national states in that vast area. Along with the economic and socio-cultural intercourse, diplomatic ties have developed into a multiform interstate relationship.

\section{The Common Cultural-Historical Provenance and the Relations} in Ancient History

That Southeast Asian Countries have a common cultural-historical origin has so far been documented by various geographers, anthropologists, paleontologists, linguists, archaeologists, ethnographers... in Việt Nam and throughout the world $_{(1)}$. We presently permit ourselves to bring to your notice a few archaeological discoveries concerning the common cultural-historical origin shared by $V$ iẹt Nam and other countries of the region.

First of all, we would like to refer to the Hoabinhian culture, whose discovery in Việt Nam dates back to the 1920s It is a mesolithic culture which was discoverd by many scientists in Việt Nam. In 1969, the Thầm Phi site (Spirit Cave), with its approximately estimated age of 10,000 years, was found in Thailand. Thầm $\mathrm{Phi}$ is considered by its excavator Ch. Gorman to be situated in the Hoabinh technical complex. Vegetal vestiges found at Thầm $\mathrm{Phi}$, such as cucumis, trapa and other leguminous plants, with their C-14 date of 9,700 B. 
東南アジアー歴史と文化一 No. 17, 1988

C., corroborate the view held by numerous scholars, namely, that Southeast Asia is the earliest region of domesticated vegetation. Recently, paddy grains were discovered in the Xóm Trai Cave (the former province of Hòa Bình, now incorporated into Hà Sơn Bình, Việt Nam) with its C-14 date of more than 10,000 years. This important discovery is now being examined.

In the second place is the $S a$ Huynh culture, whose site was first discovered in Việt Nam about 80 years ago. In the last 10 years (1975-1985), Vietnamese archaeologists have extended the excavated area, their research work being carried beyond Sa Huỳnh, encompassing a vast zone from Bình Trị Thiên to Đồng Nai-Gia Định. The results obtained further substantiate the fact that Southeast Asia, in early times, had a ceramic complex Sa Huỳnh-Kalanay(Philippines), a Sa Huỳnh-Kalanay ceramic tradition that had evolved from milleniums B. C. until the early centuries A. D.. The owners of this ceramic complex were Austronesians, whose cradle is said to be in northeastern Indonesia-southern Philippines(2). At the same time, the jar graves found at Sa Huỳnh permit a reference to similar sites in Southeast Asia, such as those of Tanjong Rawaws in Malaysia, Sabang (Sulawesi), Mélolo (Sumba), Anyar (Java), Gilimanuk (Bali) in Indonesia, Kalanay (Masbate), Boto (Sorsogon), Cagraray (Alvay)... in Philippines, and Ban Nadi in Thailand...(3).

Thirdly, the Óc Eo culture, whose site was revealed as early as the 1870 s. In the last 10 years (1975-1985), however, some excavations have shed further light on the relationship between Óc Eo and the neighbouring countries. A type of its relics-the sepulchres-came to light. This finding allows us to conclude that the owner of this culture was a Brahman population who bore the influence of the ancient Indian cultures(4) $_{(4)}$ and evidently, had close affinities with other Southeast Asian Brahman populations. The dating of these sepulchres, based on analysis of extant ashes and charcoal, fully coincides with the dating advanced by archaeologists, namely, from the 2 nd to the 5 th century A. D.(5).

The above-mentioned discoveries, relating to parts of Việt Nam, prove a common historical stock between Việt Nam and other Southeast Asian countries. Nevertheless, before mentioning the relation between ancient Viêt Nam and 
An Outline of the Relations between Viet Nam and Other Southeast Asian Countries in Ancient, Middle Age and Modern History

other Southeast Asian Countries, an insight into the affinities between Vietnamese Đong Son Culture and its neighbours is quite necessary.

It should be borne in mind that Văn Lang, to be followed by Âu Lạc, is the earliest state which came into being in Việt Nam during the first millenium B. C., when a bronze-age culture, characterized by Đông Sơn, was flourishing. The intercourse between Việt Nam and other countries in the region was particularly noted through the presence of Đông Sơn cultural objects in many Southeast Asian countries. This presence proves the existence of political relations: gifts offered during diplomatic contacts; economic relations: trading activities; cultural relations: propagated metallurgic skills, manufacture of tools, decorative patterns, and the use of implements and metal musical instruments...

We have thus far noticed the presence of Đông Sơn culture in a large part of Southeast Asia.

In the last decades, the emergence of some 10 Hager I-bronze drums was reported by H. Parmentier and V. Guahler on Thailandese territory (4 drums found at Thung Yang, upper Menam River; the 6 others at Sukhothai, Korat, Ubon, Xuot, Nakhon Sitha Maras).

Six Heger-I bronze drums were excavated in Malaysia (1 at Batu Pasiagaran, 2 at Cuala Torenganu, 1 at Kolang, 2 at Kompong Sungailang). Other bronze objects such as a bell and an urn were also found at Kolang. The scholars, including Iwao Hino and Twoodie, unanimously maintain that these objects show the traces of the Đông Sơn influence, and even opine that they originated in Đông Sơn.

Prior to the Second World War, a number of bronze objects were discovered in the Philippines, such as rings, and axes...which the archaeologist Jansé attributed to the Đông Sơn influence.

Twenty six Đông Sơn bronze drums were found on the Indonesian islands of Java and Sumatra, and scattered over Roti, Leti, and Suvalésie... Engravings on an old statue at Batu Gatja (Sumatra), patterned after bronze drums, induced Vander Hoff and other scientists to say that bronze drums had come from Việt Nam to Indonesia by way of Sumatra in the centuries B. C. The traditional Gamelan music band of Indonesia is composed of players of To Peng and 
bronze gongs...in the same manner as the bands enjoyed by the population inhabiting the Central Highland of Việt Nam.

The abundant cultural intercourse certainly takes place in parallel with the navigation and migration of populations. It is not by accident that the curvedroofed structure on piling that has gained currency in Indonesia looks very much like the habitation built on piles during the Đông Sơn culture period in Việt Nam, engraved on Ngọc $L \tilde{u}$ and Hoàng Hạ bronze drums...and the Pelog. songs of Javanese inhabitants are similar to Central Vietnamese songs.

In mentioning interstate relations, we should not pass over diplomatic activities, however meagrely recorded they may be in annals.

With regard to the times of Hùng Kings in Việt Nam, the story of the Mụ Gia Col is related in the books entitled Lĩnh Nam Chích Quái which describes the earliest peaceful diplomatic relations between Việt Nam and its neighbours to the West. Mụ Gia Col is a place in the Nghệ Tĩnh province, which connects Việt Nam and Laos. The legend has it that diplomatic activities had taken place here, aimed at delimitating the border line between the two countries (in the 1st millenium B. C.). A female envoy is said to have been sent by king Hùng to the meeting place with the representative from the neighbouring country. The departure of the two representatives should have taken place at the same time from their capital cities respectively, and the meeting place is recognised to have been the common frontier (this method of defining the frontier between different territories having becoming a common practice with early tribal societies). The female envoy of Văn Lang was called Mụ Giạ (Mụ and Giạ are two Vietnamese archaisms denoting a woman of respectable age). The meeting place of the two envoys have so far been considered as the border between Việt Nam and Laos, and has always retained its name as Mụ Giạ Col.

Another fact, as recorded in history, are the diplomatic relations established between Văn Lang State and the Chinese Chou dynasty, which bears out a peaceful dịplomacy followed by Việt Nam from time immemorial in order to preserve its own independence and contribute to safeguarding the independence of other nations in the region. According to Đại Việt Sử Ký Toàn Thư, a Vietnamese 
An Outline of the Relation between Viet Nam and Other Southeast Asian Countries in Ancient, Middle Age and Modern History

envoy, styling himself representative of Viẹt Thuờng Thi, came for the first time (1063-1026 B.C.) to the Court of Emperer Thành Vu'ong (成王) of the Chou dynasty, and offered the emperor white pheasants(6).

At that time, the Hán expansion from the Yellow River basin to the Yangtsé-kiang basin began to threaten Lạc Việt (the former Việt Nam). Many ethnoses of the Bách Việt community inhabiting Southern China had been Sinicized, whereas the Chou dynasty, in reply to the peaceful diplomacy by Lạc Việt, temporarily refrained from annexing Văn Lang. The offering of white pheasants by Việt Thường was recorded in Thượng Thu Đại Truyến (尚書大 誥), Truic Thu'Ky Niên (竹書紀年), and Hậu Hán Thu'-Nam Man Truyện（後 漢書南蛮伝), Those books also note that; According to Chu Công, the righteous people do not subdue these countries which have not received policy and orders from the Chou dynasty(7), and the Việt Thừo'ng envoy then left the Chou imperial court in a special carriage placed at his disposal by Emperor Chou. This fact shows that the peaceful and friendly diplomacy practiced by Việt Thường dissuaded the Northern Empire from invading the South, and thus enabled Southern ethnoses to live independently.

A third recorded event is the alliance between Mai Thúc Loan (alias Mai Hác Đé) and the Kingdoms of Champa and Chenla against the aggression carried out by the Chinese Tang dynasty. In the year 732, Mai Thúc Loan stood up against the aggressers in the Hoan prefecture (Nghệ Tî̃nh). It is written in the Đại Việt Sư Ký Toàn Thu that Mai Thúc Loan, occupying the prefecture and allying himself with Lâm Äp (champa) and Chenla, rallied an army 300,000 strong(8). Even the Tân Đuờng Thu (新唐書), in the chapter describing Dương Tư Húc (楊思喵), makes mention of this event; Mai Thúc Loan was in command of an army 400,000 strong(9). This strong army demonstrates the good neighbourliness between Việt Nam and the near-by countries in the common struggle against invading forces.

The three above-mentioned events, whether recorded in history or based only on traditions, have proved the fact that in former times, Viẹt Nam came into line with the larger entity of Southeast Asia, and has always followed a peaceful and friendly foreign policy towards other countries in the region 
東南アジア一歴史と文化一 No. 17, 1988

for the sake of co-existence and development. Those justifiable beginnings in building and safeguarding the country, as well as in interstate intercourse, are still preserved and developed in the present day.

\section{Interstate Relations in Middle Age History}

From the 10th century onwards, the independent state of Đậi Việt, with its flourishing economy and culture, stepped up its relations with other countries in many respects. The trading intercourse was accompanied by cultural exchanges and diplomatic activities. Military relations were sporadic and did not constitute a problem commanding the attention of the region.

As far as buisiness intercourse is concerned, it is noted in Vietnamese ancient annals that Javanese trading vessels came to Đại Việt in 1064, offering the king some precious stones, and the King paid 10,000 quan for them. As soon as buisiness activities evolved, foreign traders were allowed to settle on the islands. It is also recorded in the Đại Việt Sủ Ký Toàn Thu'; "In the second lunar month of the year Kì Ty (1149), trading vessels Trảo Ca (Java), Lọ Lac (now belonging to Thailand) and Siam came to Håi Dông (in the present day Quáng Ninh province), asking for the right to settle down and carry out a buisiness. King Lý Anh Tông authorised a business place to be established on an island, called Vân Đồn, for the exchange of precious products and the receptions of local products offered as gifts to the Court" ${ }_{(10)}$.

Since then, trading vessels from various Southeast Asian Countries frequently came to Đại Việt. In 1184, businessmen from Siam and Sumatra came to Vân Đôn to offer the king precious gifts and ask for the right to carry on a trade. In 1437, Siamese trading vessels came to Việt Nam and enjoyed a sizeable reduction in tax. In 1647, trading vessels from Sumatra came here and offered the king their local products......

Business intercourse paved the way to cultural exchange and diplomatic relations. Vietnamese annals also note that diplomatic ties were established between Đại Việt and other Southeast Asian Countries as soon as trading relations developed. After 1149, when traders from Siam, Lộ Lạc and Java had settled on Vân Đồn, an envoy from the Siamese royal court came to Việt Nam in 
An Outline of the Relations between Viet Nam and Other Southeast Asian Countries in Ancient, Middle Age and Modern History

1182, offering king Lý Cao Tông a number of gifts and proposing the establishment of diplomatic relations. In 1348, an envoy from the Javanese royal court offered the king of Đại Việt their local products, among which was a red talking parrot. In 1394, trading vessels from Java offered the king of Đại Việt an rare horse. In 1437, an Siamese envoy came to the Thăng Long capital city, offering king Lê Thái Tông many gifts. In answer to this generosity, the king of Đại Việt offered the king of Siam 24 pieces of silk, 30 assortments of porcelain bowls, and the Siamese queen 5 pieces of silk, 2 assortments of porcelain bowls (each assortment was composed of 35 bowls). In the years 1467, 1485....... envoys frequently came to Việt Nam on board trading vessels, with gifts to the king on the part of the Siamese royal court, proposing the estab. lishment of diplomatic relations. In 1647, trading vessels from Sumatra came to Đại Việt with their local products as gifts and a Javanese envoy named $\mathrm{Na}$ Bôi came here to propose business intercourse and diplomatic relations.

However, from the 10th to the 16th centuries, business intercourse between Việt Nam and other countries in the region was still underdeveloped, the manufacture of goods being below par in Việt Nam as well as in its neighbouring countries, and the economy was still acquiring a self-sufficient character. In Việt Nam,the "preferance for agriculture over business" by successive dynasties resulted in the development of foreign trade to a limited extent sufficient to support diplomatic activities.

As for cultural relations, several Buddhists bonzes on their way to India came to various South and Southeast Asian countries. Among them were many bonzes proficient in Austral languages (Malay, Sanskrit...). Buddhist, and Islamic faiths, as well as several arts and drafts (architecture, music, handicrafts ...) have been propagated from India to Việt Nam through businessmen, missionaries, and diplomatic staff....

With the development of Western capitalism in the 17th century, Netherlands, Portuguese, Spanish, British, and French, ships shuttling on the Pacific Ocean, contributed notably to the business intercourse between Việt Nam and other Southeast Asian countries. In the 17th century, Việt Nam was divided into two parts; Đường Ngoài (Northern Zone) and Đàng Trong (Sourthern Zone) with 


\section{東南アジア一歴史と文化一 No.17, 1988}

their opposed administrative powers in the hands of the Trịng and Nguyễn families respectively. During the prolonged war between the Tring and the Nguyễn from 1627 to 1672 , trading intercourse between the two zones, as well as with foreign countries, was carried on with Chinese, Japanese, and European tradespeople acting as intermediaries. Missionaries and businessmen from the West confirm the fact that the trade was thriving in the Đàng Trong (Sourthern Zone) city of Faifo (Hội An) in the 17th century, and Chinese, Japanese, Netherlans, Siamese, Malay, Portuguese, and Burmese...factories were set up here. Chinese and Siamese factories were established in the Northern Zone city of Phồ Hiến while Netherlands and British factories were found at Thăng Long capital city. The volume of trade was quite sizeable. According to Dampier, auther of the book entitled Un voyage au Tonkin en 1688, Western tradespeople bought numerous small cups from Việt Nam and then resold them in Malay Archipelago. “Already in his first voyage, Capitan Pun bought 100,000 cups and resold them to Governer Bloom of Sumatra for a reasonable price”. Besides, Netherlands tradesfolk carried with them several sorts of pavingstones, including those made at Bát Tràng and green stones, that won popularity in Southeast Asian Countries.

It should be noted that the economic integration of the three Indochinse countries was already in evidence in the 17 th century. Việt Nam was then the only outlet to the sea for the whole Indochinese peninsula. According to European businessmen, Laos sold musk and other local products to Duch merchants via Vietnamese seaports, and bought from them firearms for hunting and for selfdefence against wild beasts. Việt Nam also cooperated with Cambodia in the manufacture of commodities for export. For example, sericiculture was flourishing in the Southern Zone, yet silk breeders had to buy cereals from Cambodia for their own subsistence. This interdependence went to such length that, in 1636, when a poor harvest was gathered in Cambodia, silk production had to be reduced in the Southern Zone. Apart from that, Vietnamese seaports became the meeting places where transactions occured between gold and silver traders from China, Japan, Laos, Cambodia, Việt Nam and other countries.

It would be wrong to maintain that economic relations were impossible among 
An Outline of the Relations between Viet Nam and Other Southeast Asian Countries in Ancient, Middle Age and Modern History

Southeast Asian countries. The imports and exports of Việt Nam have dismissed this hypothesis. According to a British merchant, Bowyear by name, business intercourse was prosperous between Việt Nam and other Southeast Asian countries:

Commodities imported by Southern Zone (Đường Trong)

- From Canton, China; coins, patterned silk, ceramics, tea, zinc, mercury, ginseng, camphor...

-From Siam; betel leaves, redwood (used as a tinctorial substance), lacquer, nacre, ivory, lead, rice.

-From Cambodia; dye-stuffs, cardamon, wax, lacquer, nacre, red wood, turpentine, buffalo leather, deer leather and tendon, ivory, rhinoceros horn.

-From Batavia; silver, sandalwood, betel leaves, red and white stuffs, dye-stuffs.

-From Manila; silver, sulphor, redwood, cockle-shells, tobacco, wax, deer tendon.

Commodities exported from the Southern Zone

Gold, iron, textiles, sugar, pepper, cotton...(11).

Due to the decadence of both the Northern Zone and the Southern Zone, these business relation were somewhat discontinued in the 18th century. Towards the end of the 18th century (when the Tây Sơn insurgency broke out) and early in the 19th century (during the Nguyễn dynasty), foreign trade for was revived. Although trading activities were handicapped by the "preference agricultụre over business" and isolationist polcies were adopted by the Nguyễn dynasty, foreign trade was more or less developed, especially under the reign of Ming Mệnh and Thiệu Trị, owing to the impact of world capitalism on Việt Nam, the demands made by the royal court and the need for national defence. In 1829, King Ming Mệnh sent an envoy to Lucon (Philippines), Malaysia, Singapore and Indonesia for diplomatic and business relations. In 1830, by order of the king, the boat Uy Phưo'ng set sail for Lucon and Indonesia. In 1831, the boat Uy Phu'o'ng and the boat Thanh Dưo'ng shipped sugar to Indonesia and Malaysia. In 1835, the boats Thụy Huy and Phấn Bång set sail for Indonesia. In 1839, an envoy was sent to Djakarta and Tambalang. In 1841, a diplomatic 
東南アジア一歴史と文化一 No. 17, 1988

mission and a merchant flotilla, with the poet Cao Bá Quát on board, led by Đào Trí Phú, came to Indonesia. During the voyage, the poet wrote a poem entitled Hồng mao hỏa thuyèn $c a$ and a poem in praise of Indonesian girldancers. In the years $1841,1842,1843,1846$, trading vessels with Båo Tri Phú, Lê Vặn Phu, Tôn-thất Khương on board were sent by King Thiệu Trị to Indonesia and other countries in the region for the purpose of diplomatic and business relations. Foreign trade under the reign of Ming Mệnh and Thiệu Trị attracted the attention of European merchants. Dubois de Jancigny notes in the book entitled L'Univers-Japon-Indochine-Ceylon; that Ming Mệnh and Thiệu Trị invested a large sum in the import and export business with Singapore. In 1839, the imports and exports under the reign of Ming Mệnh totaled 1,888,423 French Francs. In 1841, under Thiệu Trị's reign this volume reached 2,906,317 Francs. Natalis Rondot, in his Dictionaire Universel Théorique et Practice du Commerce et de la Navigation (Articls "Houé") offers a clearer remark; The Nguyễn King put at the disposal of his business various European style ships equipped in the manner of warships. Each ship had a tonnage of 300-600 tonneaux $\left(1\right.$ tonneau $=2.83 \mathrm{~m}^{3}$ ), transporting goods of the King to Singapore, Batavia, Canton, Bangkok and Calcutta...Businessmen from Batavia estimated that Vietnamese sea-borne trade exceeded 30 millions Francs per year, of which over one third belonged to the king.

In the period of $1835-1839$, five boats of 500 tonneaux each left Đại Nam annually for Singapore, and four boats of 1,200 tonneaux each left Singapore for Đại Nam. During the same period, 42 boats left the ports of the Six Cochinchinese Provinces for Singapore (the tonnage of each boat being 2,900 tonneaux), and 33 boats (of 2,280 tonneaux each) weighed anchor at Singapore.

Commodities exported from Đại Nam included rice, silk, oil, leather, salt, salted fish, fish fins, drawing colours, ivory, buffalo horn, rhinoceos horn, cinnamon, turpentine, wood and sugar..., weighing about 20 million kilograms.

Commodities imported by Đại Nam included opium, wool or stuffs, silk, tea, firearms, tin wares, porcelain, footwears, spices, copper, and iron...(12). It should be stressed that the rapidly developing diplomatic and business relations constituted a favorable premise for the establishment of peaceful, friendly and cooperative ties 
An Outline of the Relations between Viet Nam and Other Southeast Asian Countries in Ancient, Middle Age and Modern History

between Việt Nam and other countries in the region. Military flares-up sometimes occured between Siam and Việt Nam, for the Vietnamese people had to defend its country or liberate those territorial parts under Siamese occupation. There were seven Siamese inroads into Vietnamese territory, and they were all repulsed. In the Rạch Cầm-Soài Mút alone, that took place in January 1785, 50,000 Siamese soldiers were routed, with only a few thousand survivers running back to their home country by several ways.

Việt Nam has always pursued a friendly foreign policy towards its neighbours. It is noted in Vietnamese annals that, in 1823, an envoy was sent by the King of Burma to Việt Nam proposing the establishment of diplomatic relations and offering some gifts; a golden stamp, 10 golden rings, 1 red lacquered betel box, and a chain of uninflamable pearls... The Burmese royal court also asked Việt Nam to sever relations with Siam, because Burma and Siam were enemies of each other. However, Việt Nam did not accept the Burmese proposal, and kept on friendly ties with both countries. The King of Đại Việt gratified the Burmese envoy with generous rewards and sent some gifts to the King of Burma. He also ordered two officers to accompany the envoy to the Burmese frontier $_{(13)}$. This event proves that the traditionally peaceful and friendly relations with neighbouring countries have long been entertained by Việt Nam, and are still being developed.

Việt Nam was invaded and ruled by the French as early as the middle of the 19th century. The intercourse between Việt Nam and other countries in the region was preserved, but the diplomatic and business relations were controlled by the colonialist and feudalist administration. The basic relations between Việt $\mathrm{Nam}$ and its neighbours were reinforced by the struggle waged by Southeast Asian people against imperialism for their own liberation.

While the three Indochinese countries were united in a common fighting against French colonialism, the Japanese fascism and the American imperialism, there was a mutual support between Việt Nam and Indonesia against French and Duch colonialism, between the anti-French people of Việt Nam and the anti-British people of Malaysia, as well as between Việt Nam and the anti-Spanish people 
東南アジア一歴史と文化一 No. 17, 1988

of the Philippines...During the Second World War, Việt Nam and its Southeast Asian neighbours always supported one another in the struggle against Japanese fascism. After the attainment of independence by various Southeast Asian countries, the interstate relationships in the region were stepped up on the basis of the spirit of the Bandung Conference (Indonesia) of 1955, the principles of the Non-aligned Movements including all Southeast Asian countries, and the principles of Peaceful Co-existence adhered by the whole region. With regard to Việt Nem and Malaysia, the friendly relations between the two countries are exemplified by the Joint Statement by Malaysian Prime Minister Abdul Raman and Vietnamese premier Phạm Văn Đồng in October 1978, during the visit of the latter to Malaysia(14). These relations have remained and developed, contributing largely to the preservation of peace and stability in the region.

These relations between Việt Nam and other Southeast Asian regions, as outlined above, are far from giving a complete picture, yet they permit us to draw a few instructive conclusions, namely;

-During some millenniums of its history, Việt Nam has always adhered to a peaceful diplomacy, a spirit of friendly cooperation with its neighbours, for the purpose of preserving the natonal independence and contributing to safeguarding peace and stability in the region.

-The similar economic and cultural features existing between Việt Nam and other countries in the region do not run counter to the regional intercourse, including trading relations. History proves that business relations among various countries in the region can and need to be promoted, once they enjoy the attention of those countries. These relations generally constitute a prelude to cultural, political, and diplomatic ties advantageous to every concerned party.

Several other historical lessons may be drawn, and to a certain extant, it is incumbent for historians to settle this task.

Notes

1) Among them are G. Coedès, H. Movius, L. Finot, H. Aymonier, P. 
An Outline of the Relations between Viet Nam and Other Southeast Asian Countries in Ancient, Middle Age and Modern History

Stern, J. Boisselier, G. Parmentier, L. Malleret, W. Solheim, Ch. Gorman, J. Prayluski, H. Fontaine, E, Saurin, Jansé....as well as Vietnamese scholars belonging to the Insititute of Archaeology, the Institute of Ethnography, the Institute of Southeast Asian Studies, the Insitute of History, the Việt Nam Museum of History, the Department of History of Hanoi University...

2) Lê Xuân Điệm "Discoveries by the Institute of Archaeology in Southern provinces over the 10 past years" Archaeological Studies, No. 4 (1985) p. 49.

3) ibid. p. 49 .

4) ibid. p. 59 .

5) ibid. p. 60 .

6) Đại Việt Sủ Ký Toàn Thú, Vol. I. The Social Sciences Editions, Hanoi. 1983. p. 119.

7）ibid. 「周公日政令不施，君子不臣其人」

8) ibid.

9) ibid.

10) ibid. pp. 337-338.

11) Thành Thế Vỹ, Việt Nam's foreign trade in the 17, 18, and early in the 19 centuries. Editions of Historical Sciences, Hanoi. 1961. p. 227.

12) ibid.

13) Đại Nam Thucc. Luc. Tome 6. Editions of Social Sciences, Hanoi. 1963. p. 252.

14) This statement defines the basic principles of the friendly and cooperative relationship between the two countries;

-To fully respect the independence, sovereignty, territorial integrity of each country and its right to choose its politic and socio-economic system.

- Not to resort to armed forces in their interrelation. To abstain from direct or indirect subversive activities.

- To settle litigation and discord that might crop up between the two countries through peaceful negotiation on the basis of equality, mutual 
東南アジア一歴史と文化一 No. 17, 1988

respect and mutual comprehension.

- To promote business intercourse and bilateral cooperation in the field of economy, technology, aeronavigation, post and telecommunication, tourism, medical science, public health, culture, sports and games.

\title{
Văn Tạo 先生のご紹介
}

\author{
桜井由躬雄
}

本論の筆者バン・タオ（Văn Tạo）氏はながらく, ベトナム社会科学委員会史学研 究所の所長をつとめられ, 歴史理論, 問題提起に関する論文を多く発表され, ベトナ ム史学界の事実上のリーダーである。日本には学術振興会の招待で1983年に来日され， 慶応大学に扣いて研究をすすめられるとともに, 本東南アジア史学会京都大会にも出 席し, 講演されたので, 多くの読者が御存じのことと思ら。本論はバンタオ氏から, 古田元夫と筆者を通じ，本紙への発表を依頼されたものである。

ベトナムの歴史研究の流れは 1954 年から 1960 年前半までの, 時代区分を中心とし た時代，1975年までの民族主義と歴史認識との関係を問題にした時代を経て，現在， 東南アジアのなかのベトナムという位置からベトナム史を再構築しようとする動きが でている。もちろん，中国・ベトナム関係の悪化にともない，社会主義圏だけにベト ナムを位置づけることが困難になったこと，アセアン諸国との関係改善が当面いそが れていることと関係している。しかしそれ以上に重要なことは, ベトナム史を周辺諸 国との関係のなかに浮かびあがらせることによって, ベトナム史を相対化しようとす るこころみであるという点である。

本論「古代，中世，近代におけるベトナムと東南アジア諸国との関係概論」は，ま ず東南アジア地域といら概念が成立しうること，各地域間の相互交渉が歴史に大きな 意味をもっていることをあらためて考えようとする。先史時代では，ホアビン・サー フイン・オケオ文化のひろがり，こうした共通の文化のなかでのドンソン文化の位置 付け，そして歴史時代と密接な関係のあるドンソン文化のひろがりは，地域間での経 済的政治的交渉が存在していたことを示すとする。嶺南嫬恠列伝の逸話からべトナム 
An Outline of the Relations between Viet Nam and Other Southeast Asian Countries in Ancient, Middle Age and Modern History

と西南諸国との，また周への越裳氏の貢納から中国との外交関係の樹立を，さらに唐 代の梅叔㝈（黒帝）の伝承から，真臘・林邑との軍事協力関係の存在を述べ，ベトナ ムが古来から近隣諸国との間に共存平和の国際関係をもっていたとする。10世紀の独 立以降では，まず雲屯におけるジャワやタイとの交易関係の発展，次にこれがもたら した文化的国際関係的な相互交渉の樹立発展を述べる。16世紀以降の展開では，ヨー ロッパ貿易船の来航がベトナムと近隣諸国との交易を活発化させたとする。17世紀以 降ではベトナムはインドシナ 3 国の唯一の海への出口として, ラオス・カンボディア は商品生産国として，相互依存関係をるったとする。19世紀にいたると，農本主義的 な阮朝のもとでも，特に1830年代から積極的に近䇟諸国, 特にシンガポール・バタビ アとの交易活動が開始される。したがって結論としてはベトナムは歷史を通じて近隣 東南アジア諸国との友好関係の樹立に努力してきたとするものである。

日本人研究者の目からすれば，もちろんいくつかの問題がある。その過度の政治主 義は持くとしても，外交という近代民族国家の成立を前提としたタームが，前近代の 国際関係，たとえば朝貢関係をさしてもちいられること，また大越史記など後世の文 献が，あたかも歴史的事実を忠実に記しているかのように扱われること，あるいは17 世紀以降のクメールが海を失ったのはとても友好関係のなかで行なわれたとは思えな いことなど，ひどく非歴史的な記述が多い。おそらく，このままではべトナム以外の 多くの東南アジア歴史家の反発を買うだろう。これは八ノイ滞在中, 史学研究所に行 く機会があれば, いつも批判していたことだけに，この欠宿はひどく残念に思う。し かしながら，これまで生産関係のなかでのみ，農業生産という観点からのみ整理され ていたベトナム歴史学のなかで, はじめて19世紀の対外交易について積極的に評価さ れてきた点は注目に価する。この方面での研究の蓄積がベトナムでなされれば，おそ らく他の東南アジフ諸国の歷史家達との対話の道が開かれるだろう。

(連絡先

京都大学東南アジア研究センター 